\title{
Studying with the Internet: Giorgio Agamben, Education, and New Digital Technologies
}

\author{
Tyson E. Lewis ${ }^{1} \cdot$ Samira Alirezabeigi $^{2}$
}

(C) Springer Science+Business Media B.V., part of Springer Nature 2018

\begin{abstract}
This paper provides an analysis of the educational use of the Internet and of digital technologies that is neither pessimistic nor optimistic, that is neither critical nor post-critical. Turning to Italian philosopher Giorgio Agamben's comments on studying and its relationship to the technology of the blank writing tablet, the authors argue that digital devises are a radical transformation in our relationship to the technologies of reading and writing. Traditionally, the scholar was able to experience his or her potentiality to communicate through writing via the blankness of the writing tablet. Yet, according to Agamben, such blankness has become inaccessible in the digital age, where the screen is always full of content. Here the authors argue that Agamben is correct in his diagnosis, yet his own theory of communicability (as the experience of our ability to and not to communicate this or that specific message) offers up a way to redeem the educational use of digital devices. It is precisely the overflowing saturation of communications on the Internet which produces a new kind of blankness. It is this blankness which should thus become the focus of a studious form of media literacy-one that is not critical or post-critical so much as pre-critical (in that it contemplates the very potentiality for communication as such).
\end{abstract}

Keywords Giorgio Agamben · Digital literacy $\cdot$ Digital education $\cdot$ Studying

Bill Ferster's (2016) book Sage on the Screen: Education, Media, and How We Learn offers an illuminating review of over 50 years of research on the effects of media and technologies on learning. As Ferster summarizes, many of the comparative media studies done show minimal or no significant difference in effectiveness (NSD) in using one form of

Tyson E. Lewis

Tyson.lewis@unt.edu

Samira Alirezabeigi

samira.alirezabeigi@kuleuven.be

1 University of North Texas, Denton, USA

2 KU Leuven, Leuven, Belgium 
media over another in improving learning outcomes. But Ferster is not pessimistic. Instead he wonders if the research has been measuring the right things. For instance, he suggests we shift from questions concerning learning outcomes to learning economies. New educational technologies have certainly increased access to learning opportunities and decreased learning time. In this sense, measuring the impacts of technologies-especially the digital variety-on learning (in terms of how, who, and what) is still an open question.

We have nothing to add to this research, instead what we would like to highlight is how Ferster frames the issue. As the title to his book suggests, we intuitively connect media and technology to questions of learning. Yet learning is not the be all and end all of education (Biesta 2006), instead it is one of many forms that education can take. When we connect technologies and learning, we ask certain kinds of questions, questions which always are oriented toward outcomes and measurements. Shifting toward learning economies as Ferster suggests is part of the logic of learning-as learning is a management of education concerned with resources and their maximal utility. But what if we made a different kind of connection? Decoupling media and technologies from learning, we want to ask another question: Can one use digital technologies to study? Study can be thought of as the suspension of outcomes and measurements that define the learning economy which Ferster unproblematically upholds (Lewis 2013, 2017). It is therefore an inoperative (rather than operative) form of educational life.

To approach the relation between digital technologies and platforms and study, we turn to Giorgio Agamben as a theorist of studying. Agamben is now widely cited in education literature as a philosopher capable of helping us think through a number of contemporary, pressing issues, including the commodification of educational potentiality within learning discourses and practices (Lewis 2013), citizenship education in a time of undocumented migrants (Zembylas 2010), as well as abandonment practice and policies in K-12 (Lewis 2006) and higher education (Harbour and Wolgemuth 2013). Despite the insights which Agamben can bring to educational issues, there has been little engagement concerning the impact of digital technologies on education from an Agambenian perspective. And this seems most peculiar given the centrality of screens and digital devices in schools and universities-including the rise of the "smart classroom" but also long-distant learning. Indeed, we might even refer to digital natives as "screenagers" (Decoster 2016) whose sense of self and community are mediated through the interface of the screen. As opposed to those who read Agamben as merely a reactionary technophobe (Stiegler 2010; Campbell 2011), Joris Vlieghe (2017) is one of the few educational philosophers to turn to Agamben in order to think through the positive potentialities of digital forms of education. For Vlieghe, Agamben enables educators to think about digital technologies beyond questions of correct and incorrect usage, and thus helps us think through another form of life not prefigured by existing normative claims concerning the educational good. Although Agamben (2009) criticizes digital technologies as leading to capture and separation, it is precisely these very conditions which generate the possibility for another way of being that suspends either technophile or technophobic reactions to digital technologies in educational discourses and practices.

In this article, we would like to pick up on Vlieghe's work and extend it somewhat in order to examine the relationship between digital technologies and study. To answer this question, we have to turn to Agamben's reflections on both studying and technology. In brief, our argument will be as follows. First, Agamben points out repeatedly that the empty or blank writing pad is the central technology of study and of contemplation. Second, the computer screen is not, for Agamben, an empty writing pad but is rather full (of icons, images, and light). The Internet is a prime example of this, as it is the sphere of perpetual 
circulation of communications without end. Third, this fullness captures thought, making it impossible to study. Up to this point, it might appear that Agamben is calling for the negation of the digital, and thus that his philosophy has little to say to educators who are interested in the question of screens in classrooms. Finally, we will ask: How can we profane the apparatus of the digital screen in order to render its form of capture inoperative? In an attempt to answer this question, we will turn to Agamben's notion of profanation in order to see how the digital screen - and the Internet in particular — can be opened up and studied. This inquiry will reveal the unique access that digital technologies and interfaces give us to the possibilities for communication. This analysis will shift focus in education away from questions of learning (where we assess the content of any given communication for its truth value) to studying (which concerns the potentiality for communication before claims of truth or falsehood can be critically assessed). In sum, we will make Vlieghe's analysis more concrete by focusing on study as a unique educational logic and on the role of the profanation of apparatuses in order to return something (like a digital screen) to free use. On this reading, it is not simply that we should reject screens or that we should adopt them as is. Rather we must profane them by suspending their unique mode of capture and separation. This would be a properly studious and free use of screens. Our analysis will, in conclusion, not only bring Agamben to bear on educational issues related to new, digital technologies, but also, will reveal how Agamben's notion of the blank writing tablet takes on a new, historically specific form in the digital era.

\section{Technologies of Study}

To begin, it is helpful to review how Agamben defines studying. He writes,

Study, in effect, is per se interminable. Those who are acquainted with long hours spent roaming among books, when every fragment, every codex, every initial encountered seems to open a new path, immediately left aside at the next encounter, or who have experienced the labyrinthine allusiveness of that "law of good neighbors" whereby Warburg arranged his library, know that not only can study have no rightful end, but does not even desire one. (Agamben 1995, p. 64)

From this citation, we see that study is interminable because it does not desire an end. It does not need ends to justify or legitimate itself. In this sense, study is neither simply a means to an end or an end in itself. Both of these formulations miss Agamben's central point which is that study prefers not to abide by the logic of ends (whether these are internal or external to its movements and gestures). Second, study is characterized as roaming through a labyrinth. It is important to note the difference here between a labyrinth and a maze. When in a maze, the subject always attempts to learn from his or her mistakes in order to escape. Thus each gesture (left or right, up or down) is subjected to evaluation in relation to an end. Over time, the subject in the maze learns which moves work, which moves help achieve an end goal (escape). Whereas a maze has an exit point, a proper labyrinth does not. Because of this, the movements and gestures within a labyrinth are indifferent to any toward or end. For this reason, walking through a labyrinth frees gestures up from being mere functional supports for a predetermined end (exit). The studier cannot learn anything from the moves made, and as such, being lost in a labyrinth enables one to experience walking as walking, full stop (hence the contemplative nature of labyrinths, as opposed to mazes). Likewise, in a library, the 
studier's thoughts are not guided toward a predetermined end point, and because of this, thinking itself can be experienced as a pure means.

Agamben continues to describe the existential experience of the studier:

But if on the one hand he [sic] is astonished and absorbed, if study is thus essentially a suffering and an undergoing, the messianic legacy it contains drives him, on the other hand, incessantly toward closure. This festina lente, this shuttling between bewilderment and lucidity, discovery and loss, between agent and patient, is the rhythm of study. (1995, p. 64)

The studier experiences a rhythm that folds back on itself. Every movement forward, recursively, turns into a movement backward (back toward the labyrinth). Thus, the studier is in a strange state of educational inoperativity whereby the thrust of learning toward an end point or goal is suspended. The agent here (the learner who has goals to meet) becomes a passive wanderer of a labyrinth. This is an educational action as not an action, or an action that produces nothing except its own ephemeral pathway. We might call studying a prolonged hesitation that simultaneously speaks to a capability to learn something and a preferring not to (complete such learning and thus move on to the next maze).

The rhythm of study is responsible for a melancholic sadness that overcomes the studier, but precisely the prolongation of this rhythm means that study ultimately turns to the very potentiality of studying itself: thought. When the studier has forgotten all goals and ends, "study shakes off the sadness that disfigured it and returns to its truest nature: not work, but inspiration, the self-nourishment of the soul" (Agamben 1995, p. 65). Thinking is no longer the content of a thought but rather shows itself as such. The invisible support which enables thoughts to come into being and concretize themselves is thrust into the foreground of thought.

The potentiality for thought never shows itself as itself in the act of learning. Because learning is oriented toward an end, potentiality is always put to use as a means to achieve this end. The instrumentalization of potentiality in the service of actualizing a capacity, talent, or interest in a measurable form means that potentiality is absorbed into the act and never makes an appearance as potentiality. It is always potentiality of and for something to be fulfilled. Hence the uniqueness of study: it is an educational activity that enables the studier to contemplate that which is otherwise absorbed into the flow of learning as an unacknowledged power. Study is not where and when something is learned, rather it is a different way of relating to that which one always already had yet remained in the deep background of one's experience. And this, for Agamben, is inspirational.

What then are the technologies of study? One possible place to start thinking about this question is in Aristotle's De anima. Here Agamben cites Aristotle's famous image of the potential intellect as a blank writing tablet. The mind, in a state of potentiality, is like a writing tablet on which nothing is written: a pure passivity that can equally receive and not receive thought. On Agamben's (1999) reading, "Just as the geometer is a geometer because he is capable of not doing geometry, and just as the kithara player is a kithara player because he is capable of not playing the kithara, so thought exists as a potential not to think (the potential intellect of the medieval), as a writing tablet on which nothing is written" (p. 215). Thinking thought itself is akin to thinking the blank writing tablet, or the non-place where thought takes place. Another name for this non-place that is also a pure taking place is khora. This ambiguous concept originated in ancient Greece and can be found in the writings of Plato where it refers to a zone of indistinction between being and nonbeing where the Platonic Forms are held. For Agamben (2017), khora is the a state 
of suspension between identities or defined actions. It is a blank writing tablet that equally contains thought and non-thought.

In Idea of Prose, Agamben offers a description of the last diadoch of pagan philosophy, Damascius who, in this reading, is an example of study. What is interesting here is how the Aristotelian metaphor of the mind as an empty tablet becomes a historically real example - the tablet of thought becomes concretized as a particular table of a particular philosopher. In 529 A.D. the emperor Justinian closed down the Athens school of philosophy. After struggling to overturn the decision, Damascius and his remaining students took what was left of their library and sought refuge at the court of the Persian king, Khosru Nushirvan. In a state of intolerable exile, lacking a formal school, Damascius began to study. He turned his attention to the aporias concerning first principles. In other words, he turns to the question of the signatures of all thought that enable thinking to take place. As Agamben recounts, he labored on this work for 300 days, and in his text, we find many statements such as: "'despite the slowness of our work, I have not, it seems, concluded anything,' or 'may God do as he pleases with what I have just written!', or again, 'all that can be said in praise of my exposition is this: that it condemns itself through its recognition of its inability to see clearly, and its impotence to look at the light" (Agamben 1995, p. 32). As a refugee, as one in exile from his homeland, he is adrift without proper status or location. In such a no-man's-land he becomes a studier-a melancholic who has entered into the interminable rhythms of thought as it tacks back and forth between pleasure and pain, undergoing and undertaking, progress and regress. Indeed, Damascius' manuscript amounted to nothing more than a prolonged hesitation, a kind of ceaseless circling.

After so much writing, Damascius suddenly lifted his head from the manuscript proper and gazed upon the writing tablet itself. He was then seized by an idea: the idea of potentiality as such. Agamben (1995) writes,

The uttermost limit thought can reach is not a being, not a place or thing, no matter how free of any quality, but rather, its own absolute potentiality, the pure potentiality of representation itself: the writing tablet! What he had until then been taking as the One, as the absolutely Other of thought, was instead only the material, only the potentiality of thought. And the entire, lengthy volume the hand of the scribe had crammed with characters was nothing other than the attempt to represent the perfectly bare writing table on which nothing had yet been written. This was why he was unable to carry his work thought to completion: what could not cease from writing itself was the image of what never ceased from not writing itself...now he could break the table, stop writing. Or rather, now he could truly begin. (p. 34)

The studier of foundations concerning first principles turned to the writing table itself as a field of pure potentiality for thought (the ability to think and not to think). The writing table became the place where non-place (khora) could emerge. This strange tale offered by Agamben gives a new educational spin on the centrality of the writing tablet for thinking about education. As Norm Friesen has recently argued (2017), educational scholars could learn much from returning to those educational forms which have endured through the centuries. He highlights how the writing table is itself one of the oldest and most stable educational media, dating back to $2500 \mathrm{BC}$ in ancient Sumer and yet persisting to this very day in the form of digital tablets. If Friesen focuses on the tablet as a reading/writing interface, Agamben enables us to pause and reflect on the blank surface itself as educational (not simply what is written upon it).

A second example of the importance of the blank writing tablet as a technology of study is found in Agamben's analysis of the connection between care of the self and creative 
activity (in particular, the act of writing). In an essay titled "Opus Alchymicum" Agamben asks what is the use of artistic work in the care for the self. It would seem that contemporary art, especially performance art, has no need for artistic works as life itself has been transformed into a work of art. Yet Agamben highlights a problem here. He warns, "with the abolition of the artistic work, unexpectedly, the work on oneself also disappears" (Agamben 2017, p. 119). If he is correct, then there might very well be a need for an intermediary creative work between a self and the aesthetic work on the self. As a point of inspiration, Agamben turns to Foucault. Agamben writes, “...the relationship with oneself and the work on oneself becomes possible only if they are linked with a creative activity. Foucault seems to suggest something similar in a 1968 interview with Claude Bonnefoy that focuses on the creative activity Foucault practiced, namely, writing" (Ibid, p. 134). For Foucault, care of the self necessarily passes through a work, the work of writing.

But why is this the case? Here we return to the idea of study. A writer can only study his or her potentiality through a work. The idea here is not that the artist or author passes into the work, rather it is that the work offers an opportunity for the artist or author to contemplate his or her potentiality to write. Agamben (2017) summarizes, “...the contemplation of a potentiality can only be given in an opus: but, in contemplation, the opus is deactivated and made inoperative and, in this way, given back to possibility, opened to a new possible use" (p. 137). The subject is therefore not reducible to a work, but rather finds itself only in the inoperativity of a work that gives itself up for contemplation. Summarized, a subject (a) creates a work in order to (b) contemplate the potentiality for writing found in the writing which (c) decreates the work or suspends it so as to return it to free use. The decreation of the work enables the non-place within the place of the work to appear, the potentiality at the heart of the work which is immanent to the work but also exceeds it. Summarizing, Agamben writes, "To think [to study or contemplate] means to recall the blank page while we write" (Ibid, p. 108). Without the blank page, contemplation of the potentiality of the self would remain inaccessible, the care of the self an impossibility.

In sum, stumbling upon the blank page or empty writing tablet is not incidental. Rather it is essential to defining the unique educational logic of studying. Without this, the rhythm of bewilderment and lucidity produce sadness rather than inspiration. This experience repotentiates thought by allowing thought to experience itself as a non-place where thought can take place. But if this is the case, can we have an experience of blankness when using digital technologies?

\section{The Fullness of Digital Screens}

Here we reach the central problem of the digital in relation to study. For Agamben, digital screens are never blank. The presumed "immateriality" of the digital screen means that the "material 'obstacle,' remains invisible and unseen in what it makes us see" (Agamben 2017, p. 107). The consequence is that we "never see the screen as such, in its materiality, because as soon as we switch it on, it fills up with characters, symbols, or images" (Ibid). We never see the screen in its materiality, only the immatetiality of the text which the screen illuminates. Because we no longer have access to the blank page, the contemplation or study of potentiality becomes inaccessible.

At first this might seem shocking as the experience of study outlined by Agamben and the experience we might have of surfing the Internet seem intimately related to one another. Briefly turning to the library and the Internet, we can compare and contrast the following 
two phenomenological descriptions of educational experiences. By highlighting the contrasts of these two experiences, we do not aim to suggest that there is a clear-cut distinction between the two, and that there is an either/or choice that we face. Rather, the contrast illuminates the fullness of the digital screen and the blankness of a white paper in relation to study.

\section{Library}

Imagine the studier who goes to the library, walks around the books that reach the ceiling. She picks a book and flickers through the pages, some parts with quick scanning and some paragraphs with a more precise reading along the lines, as the eyes move from left to right, quicker and slower, and then turning the page. Time has slowed down, as if it has stopped ticking in that building, as if the library building is time-proof. At one moment, the title of another book close at hand attracts her eyes, she picks it from the shelf and in the process of reading, having the previous text in her head, the text becomes contextualized or the context complicates itself. Studying, for her in the library comes with a feeling of floating. At the same time the train of thoughts moving from one text to the other in the spatial setting of the library is the play of lost and found. Picking the books, she walks down the aisles. Discovering a place to delve into the texts, she finds herself among the community of studiers, who sit behind their desks. She takes her flashcards out and jots down the phrases that seem the most relevant to her topic. It might happen that while reading a book, she pauses, and looks at the horizon. She is there in the library, but not quite there; her hands lead the pen to walk on the paper doodling some figures on the margin of the book, or next to her notes, while she is travelling in her thoughts. And for a moment, she pauses, stares at the cover of a closed book, at the stack of journals she has collected, or the table, or her notecards as they fan out. The whole apparatus of the library seems to condense and contract into various material objects ushering in a strange sense of stillness and silence. Suddenly, the world snaps back into focus, she takes a breath, and opens a book to flip through the pages.

\section{Internet}

Sitting at a popular café bookshop that faces the sidewalk, she opens her laptop. Her coffee by her side, she immediately opens a browser, and puts on her headphones. She is listening to the most recent album of Yann Tiersen in a player that automatically selects a playlist based on her previous music interests. She is searching on the digital catalogue of the library to find articles or books in which relations between art and education with regard to public spaces are discussed. A word document is open behind the browser on the screen and every few minutes she types things on the word document. The number of the tabs gets more and more, as she keeps clicking on different links of articles and books by means of touching the screen. Suddenly, she opens her bank account on another tab and makes a quick transaction, "rent December" she types on the message box next to the transaction. She changes the music, switching to some electronic, fast-paced music that keeps her rolling. She opens link after link, with each click she saves files and files on her hard drive. Steams of information fly by as she searches for links between art, education, and public spaces. She finds institutions in which the junction between art and education is the main research project. The more she clicks, the more papers and books she saves; she scans through the chapters of the book and the conclusion of papers, copying and pasting 
paragraphs of some chapters into the word document without saving the whole text. She has no sense of time, nor does she remember precisely her starting point. Detached from her immediate environment, the curiosity of the new, through the flickering screen, takes her away. In a parallel tab, her Facebook is open, on which she writes a message every so often, sometimes she just reads the notifications, hesitating a second or two to respond, but in the end, shifting her gaze back to the texts. Her mailbox is open in a parallel window, as she gets notifications of new emails every now and then. The world is under her fingertips as she explores the ocean of texts, exhibitions, institutions, news from the world, conversations with friends etc. Imagine mapping the clicks she makes while searching, the clicks expand into a labyrinth, in which she loses the sense of time, falling into infinite relations, opening one after the other, highlighting all the connected themes, authors, and concepts. The related themes lead to the discovery of another theme, together with the connectedness of all there is illuminates that surfing can take any direction.

\section{Comparison}

At first blush, these two phenomenological experiences of "studying" appear to be similar. Both offer up a certain sense of distracted wandering, or aimlessness. They each represent a combination of searching, note taking, clicking, chatting and typing, and they are all related to the material and immateriality of pages (of books, word documents, and instant messaging platforms on the screen). Indeed, the Internet could be seen as an ideal, virtual space for infinitely postponing any end, as the screen-space (unlike the library space) has no definitive boundaries. They also both suspend time and (at least certain) ends, creating a labyrinthlike experience. Yet this appearance of similitude is, on closer analysis, only an immaterial appearance. Key to the description above is the emphasis on the fullness of the screen, which is always already possessed of and by an infinity of icons, tool bars, links, windows, and so on. The fullness is coupled with instantaneous access. Together, these features actually make blankness impossible. Indeed, blankness is subtracted from our experience of the screen, which is always already ready-at-hand, fully loaded with tools to prompt production or consumption of itself. Stated differently, the screen is a place (rather than a non-place) populated by an overabundance of content in constant circulation. Think here of the screen saver. It "saves" the screen by perpetually filling it with images. As such, it saves the immaterial surface of the screen from its darkness, from any appearance of inoperativity. But perhaps on an even deeper level, the screen is always already illuminated with light. It is full of light from the inside, which itself is a kind of content that cannot be turned off. For Agamben, study is about looking into the dark. Here darkness is not merely a void but rather the potentiality of light as such. Agamben (1999) writes, "darkness, we may therefore say, is in some way the color of potentiality" (p. 180). Instead of seeing this or that image, in total darkness the eye can only sense its potentiality for seeing without seeing anything in particular. On this interpretation, darkness is akin to the blank writing tablet: it is a non-place that materializes its pure taking place. But if the screen is never dark, then we cannot contemplate its potentiality as such, we can only fixate on the screen as perpetual image. Indeed, the illumination of the screen means that the screen can be nothing more than its own image - its materiality is fully absorbed into its immateriality. Even the blankness of a word document on a computer screen is always already full: it is full of suggested fonts, colors, prompts, graphics, and so on. The blinking cursor is present before one starts to write, constantly reminding one to write, to write right now! The cursor is therefore the worst kind of mark, never allowing one to pause. It urges actualization of the writer's potentiality to write at every second. Moreover, the keyboard of 
the computer already presents the alphabet, the very basics of writing, suggesting the different combinations to appear on the screen. As such, immaterial content prevents the screen as a blank place from every showing itself. The implication here is that one can never study on or with a digital device.

Because they are overflowing with immaterial content, digital devices are apparatuses of capture. Agamben defines an apparatus as that which separates through capture. Moving beyond Foucault's initial definition of the apparatus, Agamben (2009) clarifies, "I shall call an apparatus literally anything that has in some way the capacity to capture, orient, determine, intercept, model, control, or secure the gestures, behaviours, opinions, or discourses of living beings" (p. 14). Although not cited by Agamben, Vilém Flusser's definition of an apparatus is also pertinent in this context. Flusser points out that the Latin word apparatus is derived from the verb meaning "to prepare." "Accordingly," writes Flusser (2016), "an 'apparatus' would be a thing that lies in wait or in readiness for something...it sharpens its teeth in readiness" (p. 21). The predatory nature of this last phrase should not be overlooked. Flusser continues to make a rather instructive distinction between the apparatus and the tool. The latter separates objects form the natural world to bring them into the human world. It does so by changing the form of the thing. We can think here of the shoe, which brings raw materials from nature into the cultural sphere by reconstructing the basic forms of the raw materials (leather, for instance). Tools are also, according to Flusser, "extensions of human organs" (Ibid, p. 23). Again, we can think of the shoe, which is an extension of the human foot. By bringing raw materials into the cultural sphere, tools shape cultural practices, changing the human world in some way. But apparatuses do not work in this manner. On Flusser's reading, apparatuses have a different intention: "to change the meaning of the world" (Ibid., p. 25). Apparatuses are therefore symbolic, concerning the creation and circulation of symbols. Instead of waiting in preparation of raw materials to separate from nature, apparatuses wait in preparation of information which they can separate from free use. Free use here refers to that which suspends or profanes the law of separation which defines the informational structure of an apparatus. Turning back to Agamben, we can say that free use is a kind of profanation that allows for the creation of a new use by deactivating an old use, rendering it inoperative. An apparatus is a program that operates on information, controlling how, when, and what circulates according to its own intentions. Perhaps we can be even more precise here and argue that apparatuses capture and separate us from an experience of our potentiality (which is not a natural resource so much as the most basic cultural and linguistic fact). They capture potentiality in their light. Profanation interrupts this operation, in turn, opening up information for free use undetermined in advance by the program of the apparatus.

The question becomes: How to render inoperative the program of the digital screen? This would mean rendering inoperative the immateriality of the screen so that users could return to its materiality (its darkness, its blankness), or its pure mediality. As opposed to technophobic or technophilic readings of Agamben, we argue that digital screens, like all apparatuses, can be profaned, rendered inoperative and that there are certain features of such devices which enable such profanation to happen. In this sense, the program of the apparatus of capture already contains within it a resource for its own neutralization.

\section{Studying the Non-Place of the Screen}

Profanation first and foremost is not a negation or destruction of something. Rather it is a suspension of something's function, its telos, or, in Flusser's language, its predatory program. As such, it would be too simple to argue that Agamben's technophobic position is 
a rejection of digital technologies. He is not advocating that we "unplug" ourselves from our devices - as if this were even possible today. Instead, we have to think about how the immateriality of the digital screen can be rendered inoperative from the inside. Another way of phrasing this would be in relation to Agamben's notion of the messianic. For Agamben, the messianic is the slightest of shifts within the present. A messianic moment is not something that is to come, something pending in the future. Rather it is an immanent moment within the present, a "tiny displacement" (Agamben 1993, p. 53) that nevertheless changes everything radically. A formulation of such a messianic moment can be found in Agamben's reflections on Paul's letter to the Romans. In Paul's writing, Agamben (2005) finds a paradigmatic case of immanent suspension that "revokes a condition and radically puts it into question in the very act of adhering to it" (p. 23). Messianic redemption is not the negation of the world but the world as not the world, slaves as not slaves, workers as not workers, or, extending this logic to the topic at hand, a digital screen as not a digital screen. Importantly, such a suspension or profanation of the screen $a s$ s screen does not posit something else to replace the screen. Agamben's formulation is a kind of negation which does not result in a positive alternative. Instead what we get is an absolute suspension where the screen is not a screen and not-not a screen. On this reading, it is important to note that Paul did not merely overturn the law. Instead he found a positive force in suspending the law. This positive force is the force of profanation that enables an experience of blankness. Such blankness turns an apparatus of capture into a counter-apparatus open for free use (not predetermined by any inscribed program).

A profanation would turn the screen into a blank tablet or, even better, redeem the material blankness of the screen from within its immaterial excess. But what would this mean, especially since Agamben emphasizes how the screen is always already full? Our suggestion is as follows. We will use the Internet as a paradigmatic case. First, we would like to highlight a rather typical, technophobic reaction to the Internet and to screen culture. The endless chatter on the Internet means that everything is communicated, but that this excessive communication devalues all communication, transforming real talk into idle talk. Here we might think of Heidegger, who diagnosed our falling condition as one of being lost in idle chit-chat. Although always embodying a certain level of abstraction, language, for Heidegger (2008), nevertheless "preserves an understanding of the disclosed world" (p. 211). But as language circulates, it becomes more and more detached from the practices which lie at its origin. What remains is a kind of "average intelligibility" that provides lessons "only approximately and superficially" (Ibid, 212). The result is a leveled-down form of communication that expresses "the possibility of understanding everything without previously making the thing one's own" (Ibid, 213). The subsequent idle talk is an everyday occurrence-indeed it is a constitutive feature of our existence. Yet Heidegger also warns that "The fact that something has been said groundlessly, and then gets passed along in further retelling, amounts to perverting the act of disclosing into an act of closing off" (Ibid, 213). It is easy to see how such a diagnosis of idle talk can be applied to the Internet. Facebook, twitter, and so on only propagate gossip, fake news, and mindless content (like cute cat pictures) that cut us off from each other and from "the facts." The result is a kind of enclave consciousness, or digital echo chamber where we only see on screen our own solipsistic image projected back to us. Substantive communications are drowned out by the tide. Thus the very fact that everything is said means that nothing is said and all communication is leveled down to meaningless verbiage (Dreyfus 2009).

We would suggest that while this is all rather bleak, the diagnosis also contain within it a potentiality for messianic profanation. And this internal profanation of the profanity of the Internet is what is so unique about it. Instead of the traditional blank tablet which 
Agamben describes, the Internet can be experienced as blank precisely because it is full! In other words, the onslaught of communications, the surge of voices, the proliferation of emoticons, the circulation of icons, the ubiquity of word clouds, the plurality of overlapping windows (screens within screens within screens within screens...) - all of this is so overwhelming that, in a moment of studious suspension, nothing at all is communicated except the simple message that communication is possible. The leveled world in which everything is accessible in its immediacy and inter-connectedness invokes a profound apathy in the user that she can go in all directions. Through this apathy the user realizes the blackness of the page. The screen is filled with so many things that it has turned black-barely anything is distinguishable except the potentiality to and not to communicate as such.

This position is radically different from the previous perspective. Digital screens can communicate the potentiality for communication without communicating anything in particular. Thus to study the digital screen means to find in the supersaturated realm of communications not this or that meaning, but rather the potentiality for generating meaning. Such would be a profanation of the circulation of idle talk of the Internet. Instead of embracing the power of the Internet as the most powerful tool ever invented to communicate or to reject it as the final blow against all communication, we can offer up the slightest of shifts in our approach, a shift that changes nothing yet everything at the same time. This would be the messianic moment of profanation inherent in studying something.

The studier lets idle the incessant feeds of immaterial information in order to step back and contemplate the material surface of the screen itself-a materiality that only becomes material in the moment of absolute saturation of immaterial communications. For Flusser, this would mean that profanation is a hack into the program of the apparatus of the digital screen, disrupting its logic of capture. Thus, study shifts the conversation from what is communicated to communicability as such - the pure potentiality for anything at all to be (and not to be) communicated.

Communicability is a pure taking place of language - a place that is really a non-place or the place where nothing actually takes place (khora). It is what is presumed in every communication but never stated. Another way of stating this might be that communicability is the gesture of language or, as Agamben (1999) argues, "the stratum of language that is not exhausted in communication" (p. 77). Precisely because communicability is never exhausted in any given communication, it provides the occasion for the continued need to communicate. Such an occasion is therefore not found outside of communication (in some external and unsayable excess, a thing in itself) but rather found within communication. Indeed, it is the very potentiality of communication to communicate-communicabilitythat is both the necessary engine for communication and precisely what cannot be communicated. In as slightly different context, Agamben points to Aristotle's analysis of the tautology "it-will-occur-or-it-will-not-occur" as an expression that is "necessarily true as a whole, beyond the taking place of either of the two possibilities" (Ibid, p. 266). Applying this to language, we might say that communicability is the experience of the potentiality of communicating and not communicating simultaneously without choosing one over the other. Instead, the whole is expressed in such a way that nothing is expressed beyond it. The non-place within place is carved out and made present.

A final expression of the tautology of communicability in Agamben is his theory of whatever. Agreeing with Guy Debord that the society of the spectacle has destroyed our ability to communicate, Agamben nevertheless finds a new, positive potentiality waiting within this catastrophe. When the spectacle appropriates real communication, what is left is a new experience of language as such, divorced from this or that specific communication. Language becomes whatever remains when communication is suspended: "not this 
or that content of language, but language itself, not this or that true proposition, but the very fact that one speaks" (Agamben 1993, p. 83). No longer attentive to the content of a message, those subjected to the spectacle are distracted by their very capacity for speech, which appears once the signifying function of language is neutralized.

On this reading, it is the greatest weakness of the Internet (its giving over of itself to meaningless memes, gossip, word clouds, blogs, and every possible kind of verbal and visual form of idle talk where truth and falsehood meet) that turns into an opportunity for studying the very preconditions for communication and its tautological structure, which always already contains within it the potentiality not to communicate. Instead of learning this or that bit of information (through Wikipedia or a quick google search), we can study that which emerges when communication becomes so dense as to implode in on itself, becoming white noise. The darkness of the Internet thus makes a surprising appearance through the unceasing illumination of the spectacle found on and through digital screens.

\section{The Politics of Study}

In conclusion, it is important to respond to a criticism of Agamben issued by Jodi Dean concerning digital technologies. According to Dean's reading, Agamben's theory of communicability, and in particular, his formulation of whatever are symptoms of precisely what the Internet already does. Thus far in this article we have argued that the infinity of communication must be profaned in order for communicability to be studied. This means that the studier suspends the function of the Internet, transforming its lightness into darkness - the darkness of the blank writing tablet. But for Dean, the Internet is already dark, it already embodies whatever (in an Agambenian sense). The whatever qualities of the Internet are symptoms of what Dean refers to as communicative capitalism which thrives on a de-politicized circulation of signifiers. "What is lost?" asks Dean (2013) when we embrace Agamben's celebration of whatever, "The ability to distinguish between contestatory and hegemonic speech. Irony. Tonality. Normativity.... Critique" (pp. 143-144). Political argumentation, struggle, and opposition cease to operate when communication becomes inoperative. Accusation and defense cease to be meaningful political activities. Wrongs against the oppressors cannot be pronounced. All that is left is an indifferent mass that does not resist so much as persist.

While Dean's reading has the virtue of pressing the question of Agamben's politics, several crucial points are missing in her analysis. To begin, Agamben is clear that what must happen is a profanation of the profanity of the spectacle. Yes, the apparatus of the Internet has captured communication and turned it into idle talk. But, when Dean reduces whatever communicability to the experience of the Internet as such, she misses how the experience of communicability demands a certain educational shift - the slightest of shifts in our relation to the circulation of communications that characterize the Internet. This educational shift is a shift from learning (about a particular communication and the truth value of its utterance) to studying the very preconditions for any given speech act in the first place (communicability). This educational shift changes nothing about the Internet while at the same time changing everything. On an average and every day level, one might indeed experience whatever in the form of a word cloud, which strips words of their signifying power. But what Agamben is after is not simply the experience of a profanation of this or that word but a profanation of the whole apparatus of profanation-the apparatus of capture. For this to occur, one must study the digital screen itself as blank, and to do 
so is to disengage from the perpetual production of communications. The studier ceases to participate in the circuits of communicative capitalism in order to contemplate them. Whereas Dean wants to posit that an experience of communicability negates politics, we would argue that nothing is negated here (as that would contract Agamben's own methodological principles). Instead of a post-political educational philosophy what we find instead is a pre-political educational philosophy: the study of first principles, which hits upon the potentiality for communication and thus hits the very preconditions for producing a new politics without predetermining what shape such politics might take. When Dean (2013) writes, "I can locate here neither a politics I admire nor any struggle at all" (p. 141), she is attempting to learn something about politics from Agamben's work by placing it within existing frameworks of struggle. Instead, we suggest that we study Agamben's thoughts on digital technologies in order to discover the non-place of communicability that will enable us to think a new foundation for what counts as politics in the first place.

In this sense, study is not post-critical or a-critical so much as pre-critical. It exposes the studier to the preconditions for all forms of criticality: communicability as such. Whereas criticality is the ability to determine fake versus real news (for instance) and thus make distinctions (make informed moves within the maze of information), in the experience of communicability, such distinctions are held together tautologically as equal possibilities of any communicative act (opening up a labyrinth). Communicability does not choose one over the other. Instead, it returns us to the primordial experience of communication that exists before this or that particular message is communicated. This is equivalent to returning to the blank writing tablet where all thoughts are contained in potential. Such an experience is not something which is immediately present in our daily use of digital technologies. Instead it emerges through a studious suspension of the suspension of these information technologies. And here, we find a certain kind of messianic suture where Damascius and his blank writing table suddenly return after centuries of exile to the far shore of our digital universe to remind us of the use of the non-place of study.

\section{References}

Agamben, Giorgio. 1993. The coming community. Minneapolis: University of Minnesota Press.

Agamben, Giorgio. 1995. The idea of prose. New York: SUNY Press.

Agamben, Giorgio. 1999. Potentialities: Collected essays in philosophy. Stanford: Stanford University Press.

Agamben, Giorgio. 2005. The time that remains: A commentary on the letter to the Romans. Stanford: Stanford University Press.

Agamben, Giorgio. 2009. What is an apparatus?. Stanford: Stanford University Press.

Agamben, Giorgio. 2017. The fire and the tale. Stanford: Stanford University Press.

Biesta, Gert J.J. 2006. Beyond learning: Democratic education for a human future. London: Routledge.

Campbell, Timothy C. 2011. Improper life: Technology and biopolitics From Heidegger to Agamben. Minneapolis: University of Minnesota Press.

Dean, Jodi. 2013. Whatever blogging. In Digital labor: The internet as playground and factory, ed. Trebor Scholz, 127-146. New York: Routledge.

Decoster, Pieter-Jan. 2016. The significance of digital screen culture for education. In Afterschool: Images, education, and research, ed. Nancy Vansieleghem, Joris Vlieghe and Pieter Verstraete, 51-66. Leuven: Leuven University Press.

Dreyfus, Hubert. 2009. On the internet. New York: Routledge.

Freisen, Norm. 2017. The textbook and the lecture: Education in the age of new media. Baltimore: John Hopkins University Press.

Ferster, Bill. 2016. Sage on screen: Education, media, and how we learn. Baltimore: John Hopkins University Press.

Flusser, Vilém. 2016. Toward a philosophy of photography. London: Reaktion Books. 
Harbour, Clifford P., and Jennifer R. Wolgemuth. 2013. Giorgio Agamben and the abandonment paradigm: A new form of student diversion in public higher education. The Review of Higher Education 36(2): 235-254.

Lewis, Tyson E. 2006. The school as an exceptional space: Rethinking education from the perspective of the biopedagogical. Educational Theory 56(2): 159-176.

Lewis, Tyson E. 2013. On study: Giorgio Agamben and educational potentiality. New York: Routledge.

Lewis, Tyson E. 2017. Inoperative learning: A radical rewriting of educational potentialities. New York: Routledge.

Stiegler, Bernard. 2010. Taking care of youth and the generations. Stanford: University of Stanford Press.

Vlieghe, Joris. 2017. Education in an age of digital technologies: Flusser, Stiegler, and Agamben on the idea of the posthistorical. Philosophy and Technology 27(4): 519-537.

Zembylas, Michalinos. 2010. Agamben's theory of biopower and immigrants/refugees/asylum seekers: Discourses of citizenship and the implications for curriculum theorizing. JCT. Journal of Curriculum Theorizing 26(2): 31-45. 